\title{
Appointment of Constitutional Judges in a Comparative Perspective - with a Proposal for a New Model for Hungary**
}

\begin{abstract}
This paper discusses the different models of appointment applied for constitutional judges in Europe, taking into consideration also the appointment procedure of the two European regional courts. It offers an account and a comparative analysis of the three appointment models: the split, the collaborative and the parliamentary model, discussing their practical application and shortcomings. In particular, the paper deals with the question of how to avoid standstills in the different appointment procedures and with the publicity of these procedures. The author concludes with a proposal for the Hungarian Constitutional Court, arguing that the split model is the one that ensures better that the composition of the Court expresses a balance between the branches of government.
\end{abstract}

Keywords: Comparative law, judicial independence, constitutional courts, appointment of judges, Hungarian law

\section{Introduction}

The procedure followed for the appointment of constitutional judges is an essential element of a constitutional justice model and affects significantly the court's self-perception. When creating a new constitutional court it is a fundamental question who and how can become a member of it. Indeed, this fundamental question is composed of two elements: first, who can become a judge, i.e. the requirements to be fulfilled; second, how one can become a judge, i.e. the procedure to be followed to appoint a new judge. This paper is going to focus on the second element.

When a country decides to set up a constitutional court, the first step is to determine what role the court is supposed to play in the legal system. The question in a more simple way is: is the constitutional court really a court? Even if the answer seems obvious, given that it is called constitutional court, the question is under continuous debate among legal scholars and political scientists. Some consider the constitutional court a political body, arguing that the most important function of a constitutional court, i.e. that of evaluating the constitutionality of legislation and annulling unconstitutional laws, is a political activity. According to them the activity of a constitutional court is a kind of "negative legislation", since it suppresses what the legislator enacted. Hans Kelsen himself argued that constitutional adjudication is law-creation. However, he believed that even the activity of ordinary judges is so. ${ }^{1}$ For him the difference between a legislative act and a judicial

* Ph.D., Senior Lecturer, Örebro University, SE-701 82 Örebro, Sweden.

E-mail: kelemen_kata@yahoo.com

** This paper is based on an article published (in Hungarian) before the adoption of the new Hungarian Fundamental Law in Új Magyar Közigazgatás, 4 (2011) 4, 2-14, entitled Az alkotmánybírák választása Európában és hazánkban.

1 " $[\mathrm{T}]$ he act of the court is not simply a matter of pronouncing or discovering the law already complete in the statute, the general norm. Rather, the function of adjudication is constitutive through and through; it is law creation in the literal sense of the word. (...) [I]t is the continuation of the process of creating law - out of the general, the individual." See Kelsen, H.: Introduction to the problems of legal theory (translated by B. Litchewski Paulson and S. L. Paulson). Oxford, 1992. 68. 
decision is in the extent to which that decision is political. This paper is not going to go deeper into this question, but it is important to notice that the debate is far from settled. Defining constitutional courts is made even more difficult by the fact that there are no two identical constitutional courts in Europe, and probably in the world. Both in composition and in the exercised powers we can find several combinations. Consequently, there are several role conceptions. In general we can observe that they are mostly considered sui generis bodies that belong neither to the judicial nor to the legislative power. ${ }^{2}$ With the words of András Holló, former President of the Hungarian Constitutional Court, a constitutional court is "an autonomous actor of public law and power which is in a relationship of mutual sub- and co-ordination with the parliament". ${ }^{3}$ According to another former constitutional judge, Géza Kilényi, the only common feature of constitutional courts and ordinary courts is judicial independence. They differ considerably in all the rest: place in the organization of the state, nature of the activity, powers, procedure. ${ }^{4}$

\section{Independence of constitutional judges}

The appointment procedure is the point where constitutional justice and party politics intertwine in the most evident and manifest way. The members of the constitutional court are appointed by politicians at least in part in every constitutional justice model. However, there are several safeguards built in to the system in order to protect the judges' independence. So, as regards constitutional judges, it may be more proper to talk about "becoming independent" rather than "being independent", since most of them are appointed thanks to the support of one or more political parties. The principal aim in the appointment procedure is not that of appointing persons of unknown political beliefs (in reality political beliefs are essential in choosing the candidates), but ensuring that once a person is appointed he or she can work without any pressure or influence by political or other external actors. The most evident example illustrating this is the American system, where the appointment of Supreme Court Justices is a clear political choice, while there are several guarantees aiming at relieving the judges from any external pressure. Among these guarantees we can find life tenure and the prohibition of lowering the judges' salaries, both provided by the federal Constitution. ${ }^{5}$

However, there is another side of the coin. The price of a complete independence is the lack of accountability. Solving the conflict between these two values is a difficult task. With the words of Volcansek, "reconciling independence with accountability may be akin to squaring a circle". ${ }^{6}$ The European legal tradition prefers independence. It presumes that judicial independence ensures correct adjudication.

Furthermore, it is important to distinguish independence from impartiality. In this respect there is a fundamental difference between ordinary and constitutional courts. In

2 See, e.g. Stone Sweet, A.: Governing with Judges. Oxford, 2000. 34.

${ }^{3}$ See Holló, A.: Alkotmánybíráskodás Magyarországon. Az első 9 hónap gyakorlatának tükrében (Constitutional justice in Hungary. In the light of the practice of the first 9 months). Magyar Közigazgatás, (1991) 1, 744-745.

${ }^{4}$ See Kilényi, G.: Az alkotmányosság - belülröl nézve (Constitutionality - as seen from the inside). Acta Humana, (1990) 2, 29.

5 Article III, Section 1 of the U.S. Constitution.

6 See Volcansek, M. L.: Appointing judges the European way. Fordham Urban Law Journal, 34 (2007), 363-385, 364-365. 
ordinary (criminal, civil, administrative, etc.) court procedures there are parties facing each other. In this context impartiality means that the judge cannot be prejudiced or in any way connected to any of the parties. In constitutional adjudication the notion of impartiality gains a different meaning if the court exercises abstract review, since in this case there are no parties. The applicant cannot be considered a party in the traditional procedural sense. The conflict is not between two parties but between two norms. In this context impartiality is not required with respect to the parties but with respect to the other branches of government, the legislator and the executive.

Finally, it is worth to be observed that judicial independence is not an absolute concept. It is not a feature which does exist or does not exist. Independence is a complex notion that has several gradations and shades.

\section{Questions of comparative methodology}

In this comparative study only constitutional courts have been involved, while supreme courts have been excluded from it. The reason is simple: from the point of view of judicial appointments they are not comparable. In continental European countries the appointment of supreme court judges is not a political choice but a internal administrative decision. They are usually appointed by the Head of the State (the President of the Republic or the King) on proposal by the judicial council among judges of the courts of appeal, on the basis of seniority and the number of delivered judgments.

Constitutional courts and supreme courts differ considerably also in the number of their members. The latter are much larger. In Hungary, for example, the Constitutional Court is composed of 15 members, while the Supreme Court works with 88 judges, but in other countries the number of supreme court judges is even bigger (the French Cour de cassation, for examples, has nearly 200 members $^{7}$ ). This difference results in divergent decisionmaking mechanisms. A continental European supreme court never takes decisions in plenary session, while it is the rule for most constitutional courts, at least as regards the decisions taken in the ambit of constitutional review of legislation. In Hungary, the harmonization panel of the Supreme Court (in charge of ensuring uniformity of case-law) is composed of 7 judges, ${ }^{8}$ while the Assemblée plénière of the French Court of Cassation may comprise up to 25 judges, but there are no cases in which all judges participate in the decision.

The Supreme Court of the United States cannot be considered a typical supreme court, and it differs even from the supreme courts of other common law countries. This organ, which plays an essential role in the system of checks and balances, is composed of nine members appointed by the President, which represents the executive power, with the advice and consent of the upper house of the Congress (the Senate). ${ }^{9}$ The appointment procedure is admittedly politicised, but the veto power of the Senate guarantees that the President will not choose persons who are unsuitable for the position. An even more important feature of the American system of administration of justice is the prerogative of the Supreme Court to select the cases it deems worthful to be decided. ${ }^{10}$ This is also the reason why it is quite

7 See Bell, J.: Judiciaries within Europe. A Comparative Review. Cambridge, 2006. 47.

8 See art. 30 (2) of Act no. LXVI of 1997 on the organization and administration of the judiciary.

9 Article II, Section 2, paragraph 2 of the U.S. Constitution.

10 And the Court actually uses this prerogative. According to statistics, on average it decides 70 cases a year out of 8 thousand. See Abraham, H. J.: The judicial process. 7th ed., New York-Oxford, 1998. 190-202. 
common to compare the U.S. Supreme Court to constitutional courts, since it often uses its prerogative to hear cases of a constitutional nature. ${ }^{11}$ Furthermore, in the U.S. legal system the ordinary judges have the power of judicial review, so in practice the Supreme Court also functions as a constitutional court.

The French Conseil constitutionnel is not included in the analysis, as it did not grow out of the idea of constitutional justice of Hans Kelsen. It constitutes a sui generis body which was for a long considered to be a political one. ${ }^{12}$ Even if the constitutional reform adopted in 2008 changed the French model by introducing a posteriori concrete review, exercised through the exception d'inconstitutionnalité, it is still early to evaluate its impact and practical application. ${ }^{13}$

\section{International recommendations and international courts}

Before examining the issue from a comparative perspective it is worth considering the international legal environment and whether there is any international obligation in relation to the appointment of constitutional judges. The answer is simple: there is no international obligation of this kind. However, the well-known consultative body of the Council of Europe, the Venice Commission dealt with the issue in the ambit of its analyses of constitutional justice and expressed its opinion. The appointment of judges to the two European courts, the Court of Strasbourg and the Court of Luxembourg, are also significant examples for the European countries.

\section{Recommendations of the Venice Commission}

A Vademecum on Constitutional Justice issued in $2007^{14}$ deals also with the issue of appointment of judges, and it points out that ensuring democratic representation in the procedure may endanger the stability of the institution, as it is reliant on a political agreement, if the system does not provide safeguards in case of a vacant position. Instability can occur when, in lack of political consensus about the candidates, a number of vacancies

11 See, e.g. Tushnet, M.: Comparative constitutional law. In: Reimann, M.-Zimmermann, R. (eds): The Oxford Handbook of Comparative Law. Oxford, 2006. 1225-1257. However, as noted by Richard A. Posner, the percentage of Supreme Court cases that are primarily constitutional has not exceeded 50\% in recent years. See Posner, R. A.: Supreme Court, 2004 Term. Harvard Law Review, 119 (2005) 1, 28-102, 37-38.

12 About the discussion over the nature of the Conseil constitutionnel see, e.g. Stone Sweet, A.: The politics of constitutional review in France and Europe. International Journal of Constitutional Law, 5 (2007) 1, 69-92.

13 The reform entered into force in 2010. See more in Fabbrini, F.: Kelsen in Paris: France's Constitutional Reform and the Introduction of A Posteriori Constitutional Review of Legislation. German Law Journal, 9 (2008) 10, 1297-1312.

${ }^{14}$ See section 4.3 of the Vademecum on Constitutional Justice, European Commission for Democracy Through Law (Venice Commission), Strasbourg, 11 May 2007, CDL-JU(2007)012, available at http://www.venice.coe.int/ docs/2007/CDL-JU\%282007\%29012-e.asp (last access on 21 December 2012). A Vademecum is a compilation of extracts taken from opinions adopted by the Venice Commission on a given issue. It specifically aims at serving as a source of reference for drafters of constitutions and of legislations on constitutional courts, researchers as well as the Venice Commission's members, who are requested to prepare comments or expertises (see the Introduction of the Vademecum cited above). 
persist for a long time. This can endanger the functioning of the court if the number of judges is close to the quorum required by the law. This danger has been real for more European constitutional courts, such as the Hungarian and the Czech ones. ${ }^{15}$

The Venice Commission recommends the split model (or, as it calls it, "mixed model"), providing elective or appointment powers to the three main branches of power and having more democratic legitimacy. ${ }^{16}$ The Vademecum deals also with the question of the majority required for the appointment of new judges. This question obviously emerges only in relation to the parliamentary appointments. The Venice Commission brings the example of Germany as a "satisfactory experience", as it requires two-thirds majority and involves different state organs and political forces into the appointment process so that the judges are seen as being more than the instrument of one or the other political force. According to the Commission, much of the general respect which the German Constitutional Court enjoys is due to the broad-based appointment procedure for judges. ${ }^{17}$

The Vademecum frequently cites and relies on a study undertaken ten years earlier, analysing the composition of constitutional courts. ${ }^{18}$ This study makes a distinction between direct appointment and election. The former means that there is no vote, but a single person decides on the appointment. In its pure form it is not used in anywhere anymore. It was the case in France until the recent constitutional reform adopted in 2008. ${ }^{19}$ However, this paper, for the reasons already mentioned above, does not involve the French system in the analysis. The elective system, on the other hand, means that the power of appointment is exercised by a body, not a single person. ${ }^{20}$ Most of the appointment systems mix these two methods in their own way. ${ }^{21}$

15 In the Czech Republic the Constitutional Court's composition was uncomplete for more than two years between 2003 and 2005. A detailed account of the events can be found in Kühn, Z.-Kysela, J.: Nomination of Constitutional Justices in Post-Communist Countries: Trial, Error, Conflict in the Czech Republic. European Constitutional Law Review, 2 (2006), 183-208, 194-198. See more infra at IV.

16 See section 4.3 of the Vademecum. This recommendation is an extract from an opinion delivered on draft constitutional amendments with regard to the Constitutional Court of Turkey in 2004.

17 See section 4.3.1 of the Vademecum. This recommendation is an extract from an opinion delivered on a proposal to amend the Constitution of Moldova in 2004.

18 See section 1.1 in The Composition of Constitutional Courts, European Commission for Democracy Through Law (Venice Commission), Strasbourg, December 1997, CDL-STD(1997)020, available at http://www.venice.coe.int/docs/ 1997/CDL-STD\%281997\%29020-e.asp (last access on 21 December 2012). The study consists in a report on 40 courts in the world, also outside Europe. Notwithstanding its title, also supreme courts are involved in the analysis in the case of countries which do not have a constitutional court (e.g. Cyprus, Finland, the Netherlands, Japan and Canada).

19 Today the President of the Republic and the Presidents of the two Houses of the Parliament, shall exercise their power of appointment after public consultation with the relevant standing committee in each house. See art. 13 and 56 of the French Constitution as amended by Act no. 2008724 of 23 July 2008.

${ }^{20}$ All constitutional judges are elected in, e.g. Germany, Hungary, Lithuania, Portugal and Slovenia.

${ }^{21}$ See more infra at III. 


\section{Appointment of judges to the European regional courts}

The European Court of Human Rights (hereinafter: Court of Strasbourg) is often compared to constitutional courts due to its partially analogous function: judicial review of legislation from a human rights perspective. ${ }^{22}$ Its task is to decide if the Contracting States comply with the European Convention on Human Rights. It is on the other hand questionable if the Court of Justice of the European Union (hereinafter: Court of Luxembourg) can be compared to constitutional courts, as it differs considerably both in its composition and in its jurisdiction. $^{23}$

As regards the composition, the fact that the judges have different nationalities is an important point, because it gives judicial independence a more complex meaning. In this context the judges' impartiality has to be examined not only in relation to the parties or the other branches of government, but also in relation of the judges' country of origin. There are a few studies analysing this aspect with respect to the Court of Strasbourg, ${ }^{24}$ while in the case of the Court of Luxembourg an analysis is made impossible by the high level of secrecy that characterises the Court's work. The judgments delivered in Luxembourg are apparently unanimous, as there is no possibility for the judges to publish their dissent. Therefore the public cannot know which judges voted for and against the decision in a given case. ${ }^{25}$

Even though the number of judges on both European courts is equal to the number of members states, so the Court of Strasbourg has 47 and the Court of Luxembourg has 27 judges, the appointment procedure is different. The judges of Strasbourg are elected by the Parliamentary Assembly of the Council of Europe from a list of candidates nominated by the Contracting Parties. ${ }^{26}$ Protocol No. 14 to the Convention, adopted on 1 June 2010, abolished the possibility of re-election and increased the term of office from six to nine year, but it did not change the appointment procedure. ${ }^{27}$ The judges of Luxembourg are

22 See, e.g. Stone Sweet, A.: On the Constitutionalisation of the Convention: The European Court of Human Rights as a Constitutional Court. Faculty Scholarship Series. Paper 71 (2009). At $\mathrm{http} / / /$ digitalcommons.law.yale.edu/fss_papers/71 (last access on 21 December 2012).

23 The problem of comparability is discussed by Michel Rosenfeld in an essay published in 2006, even if he focuses on comparison with the U.S. Supreme Court. See Rosenfeld, M.: Comparing Constitutional Review by the European Court of Justice and the U.S. Supreme Court. International Journal of Constitutional Law, 4 (2006), 618-651, available also online at http://www.ecln.net/ elements/conferences/book_berlin/rosenfeld.pdf (last access on 21 December 2012).

${ }^{24}$ For example the Dutch Fred J. Bruinsma who published two studies on the topic: Judicial Identities in the European Court of Human Rights. In: Van Hoek, A. et al. (eds): Multilevel Governance in Enforcement and Adjudication. Antwerpen, 2006. 203, and, with M. de Blois, Rules of Law from Westport to Wladiwostok. Separate Opinions in the European Court of Human Rights. Netherlands Quarterly of Human Rights, 15 (1997) 2, 175-186.

${ }^{25}$ See Laffranque, J.: Dissenting Opinion in the European Court of Justice. Juridica International, 9. (2004), 14-23. available also at http://www.juridicainternational.eu/public/pdf/ ji_2004_1_14.pdf (last access on 21 December 2012).

${ }^{26}$ Each Contracting Party nominates three candidates. See art. 22 of the European Convention on Human Rights.

27 For a thorough analysis of Protocol No. 14 see Mowbray, A.: Protocol 14 to the European Convention on Human Rights and Recent Strasbourg Cases. Human Rights Law Review, 4 (2010) 2, 331-354. 
appointed by common accord of the governments of the Member States, after consultation of a panel composed of seven experts. ${ }^{28}$ This panel was introduced by the Lisbon Treaty, which entered into force on 1 December $2009 .{ }^{29}$

\section{The appointment of constitutional judges from a comparative perspective}

Examining the different models and legislative solutions is a common practice when preparing a constitutional reform, like the one recently adopted in Hungary, ${ }^{30}$ since the experience of other countries can always teach the drafters a lot about the different possible solutions. As a starting point a table summarizing the appointment procedures used by European constitutional courts (Table 1):

Table 1

\begin{tabular}{|l|l|l|}
\hline Country & $\begin{array}{l}\text { Number } \\
\text { of judges }\end{array}$ & Appointment procedure \\
\hline Austria & 14 & $\begin{array}{l}8 \text { members on proposal by the federal government, 3-3 members } \\
\text { on proposal by the two houses of the parliament } \rightarrow \text { the federal } \\
\text { president appoints them }\end{array}$ \\
\hline Bulgaria & 12 & $\begin{array}{l}3 \text { members appointed by the head of state, 3 by the parliament, 3 } \\
\text { by the two supreme courts jointly }\end{array}$ \\
\hline Czech Republic & 15 & the head of state appoints them with the consent of the Senate \\
\hline Germany & 16 & $\begin{array}{l}8-8 \text { members elected by the two houses of the federal parliament } \\
\text { (out of whom 3-3 members have to be former judges of one of the } \\
\text { federal supreme courts) }\end{array}$ \\
\hline Hungary & 15 & $\begin{array}{l}\text { ad hoc parliamentary committee composed of representatives of all } \\
\text { parliamentary parties reflecting the parliamentary strength of the } \\
\text { parties } \rightarrow \text { two-thirds majority voting }\end{array}$ \\
\hline Italy & 15 & $\begin{array}{l}5 \text { members elected by the two houses of the parliament in joint } \\
\text { session, 5 members appointed by the head of state, } 5 \text { members } \\
\text { appointed by the three supreme courts (2 by the Court of } \\
\text { Cassation, 2 by the Council of the State, 1 by the Court of } \\
\text { Auditors) }\end{array}$ \\
\hline
\end{tabular}

28 These seven persons are to be chosen from among former members of the Court of Justice and the General Court, members of national supreme courts and lawyers of recognised competence, one of whom shall be proposed by the European Parliament. The panel is set up by the Council of the European Union. See art. 254 and 255 of the Treaty on the Functioning of the European Union. The President of the first Panel set up in 2010 is the French Jean-Marc Sauvé, Vice-President of the Conseil d'État. See Council Decision of 25 February 2010 appointing the members of the panel provided for in Article 255 of the Treaty on the Functioning of the European Union (2010/125/EU).

${ }^{29}$ For a more detailed analysis of the appointment procedure of the Court of Luxembourg see the paper by Camilla Cordelli published in this issue.

30 Hungary adopted a new constitution in April 2011, called Fundamental Law (Alaptörvény in Hungarian), which entered into force on 1 January 2012. 
Table 1. (Continued)

\begin{tabular}{|c|c|c|}
\hline Country & $\begin{array}{l}\text { Number } \\
\text { of judges }\end{array}$ & Appointment procedure \\
\hline Latvia & 7 & $\begin{array}{l}3 \text { members on proposal by at least } 10 \text { members of the parliament, } \\
2 \text { members on proposal by the government, } 2 \text { members on } \\
\text { proposal by the supreme court } \rightarrow \text { the parliament appoints them }\end{array}$ \\
\hline Poland & 15 & $\begin{array}{l}\text { on proposal by } 50 \text { members of parliament or the Presidium } \\
\rightarrow \text { the lower house of the parliament (Sejm) elects them by } \\
\text { absolute majority }\end{array}$ \\
\hline Portugal & 13 & $\begin{array}{l}10 \text { members elected by the parliament, } 3 \text { members co-opted by } \\
\text { the constitutional court itself }\end{array}$ \\
\hline Romania & 9 & $\begin{array}{l}3-3 \text { members elected by the two houses of the parliament, } \\
3 \text { members appointed by the head of state }\end{array}$ \\
\hline Spain & 12 & $\begin{array}{l}\text { 4-4 members on proposal by the two houses of the parliament } \\
\text { (by three-fifth majority), } 2 \text { members on proposal by the } \\
\text { government, } 2 \text { members on proposal by the General Council } \\
\text { of the Judiciary } \rightarrow \text { the King appoints them }\end{array}$ \\
\hline Slovakia & 13 & the President of the Republic on proposal of the parliament \\
\hline Slovenia & 9 & $\begin{array}{l}\text { the lower house of the parliament by absolute majority in secret } \\
\text { voting, on proposal by the President of the Republic }\end{array}$ \\
\hline
\end{tabular}

By examining Table 1, one may notice first of all that there are no two identical appointment procedures among those reported. Each county elaborated its own system and goes its own way. However, it is still possible to classify them in three groups. The classification proposed by Wojciech Sadurski in relation to the constitutional courts of Central and Eastern Europe can be easily extended to constitutional courts in general. ${ }^{31}$

\section{The split model}

In the split model (or "mixed model", as called by the Venice Commission ${ }^{32}$ ) more bodies share the power of appointment. It means that different bodies appoint a certain number of judges, or nominate a certain number of candidates when the final decision is taken by the parliament (e.g. in Latvia) or the Head of the State (e.g. in Spain). In this group we may find Bulgaria, Latvia, Italy and Spain. The gist of the model is that the power of appointment is shared by all three branches of government: besides the executive and the legislative also the judicial branch, which can choose new members to the constitutional court among its own judges. Consequently, in this model there are quotas. A number of the constitutional judges are elected by the parliament, a number of them are appointed by the government, and a number of them by the supreme court(s). The most common solution is to share these quotas equally, so the number of constitutional judges is usually divisible by three. An exception is the Latvian Constitutional Court which is composed of seven members, two-

${ }^{31}$ For Sadurski's original classification see Sadurski, W.: Rights Before Courts. Dordrecht, 2005. 15-16. and Sadurski, W.-Lach, K.: Constitutional Courts of Central and Eastern Europe: Between Adolescence and Maturity. Journal of Comparative Law, 3 (1998) 2, 212-233.

32 See note 17 and corresponding text. 
two of whom are nominated by the government and the Supreme Court, while the parliament can choose three candidates. ${ }^{33}$

A special variant of the split model was introduced in Romania which adopted the French model, even if with important variations. Three members are appointed by the President, ${ }^{34}$ while other three-three members by the two houses of the parliament. This system differs from the French one because while the members of the Conseil Constitutionnel are appointed by the Presidents of the two houses ${ }^{35}$ in Romania this power is exercised by the houses themselves. ${ }^{36}$ In France there is no vote, while in Romania the houses decide by absolute majority ${ }^{37}$ One can even argue that it is not a true split model, since the judicial branch is not involved in the appointment procedure, but it is still split in the sense that the different bodies act independently from each other and do not have to cooperate in the appointment. ${ }^{38}$ The Romanian model is closer to the split model in a period of cohabitation, while it gets closer to the parliamentary model in times when the President of the Republic and the Prime Minister represent the same political party, and all candidates may be chosen by the same political force. The Romanian experiences, however, show that in practice it is the President who is the central figure in the appointment procedure. His impact is somewhat lower when the government is based on a coalition than when there is a mono-party government. ${ }^{39}$

\section{The collaborative model}

In the second model of appointment there is cooperation between the executive and the legislative branches. It differs from the split model in that the different bodies involved in the appointment procedure do not act independently (as in the Romanian solution), but they have to collaborate. Hence the name "collaborative model".

This model also has a number of variants. The prototype is the American (U.S.) model, in which federal judges are appointed by the President with the "advice and consent" of the Senate, the upper house of the Congress. ${ }^{40}$ This solution has been adopted faithfully only by the Czech Republic. It is a real curiosity in comparative constitutional law, as the Czech Republic is not a presidential republic, and not even a semi-presidential one, but its form of government is a parliamentary republic. Neither the President nor the Senate is comparable to its American counterpart. The Czech President is elected by the parliament, his powers

33 All candidates shall be confirmed by the parliament. See art. 4 (1) of the Latvian Constitution, available in English at http://www.satv.tiesa.gov.lv/?lang=2\&mid=9 (last access on 21 December 2012).

34 Romania is also a semi-presidential state, so the President of the Republic is part of the executive branch.

35 See art. 56 of the French Constitution.

36 Furthermore, the former Presidents of the Republic are not members of the Romanian Constitutional Court.

37 See art. 6 (4) of Law no. 47 of 1997 on the organization and operation of the Constitutional Court.

38 See Sadurski-Lach: op. cit. 223.

39 See Sadurski, W.: op. cit. 307, note 136. Wojciech Sadurski bases his statement on an interview made with Cristian Parvulescu, professor of political science in Bucharest.

40 About the appointment of judges in the United States see Abraham: op. cit. 54-90. 
are very limited and most of them require a countersign by the government. ${ }^{41}$ The Czech Senate (Senát) differs from the American one both in its composition and in its powers. The Czech Republic is not a federal state, consequently the upper house of the parliament does not serve as representative of the states' interests, and not of those of local governments. The 81 Czech senators are elected directly by the citizens, under the principles of the majority system. ${ }^{42}$ Also, the Czech party system is different in that it is much more fragmented. So why did then the Czech Republic choose the American model of appointment? According to the official explanation it is supposed to be an expression of a system of checks and balances, in which the Senate controls the appointment of constitutional judges. Actually it is one of the most important powers for both the President and the Senate in the Czech Republic, as they both play a limited role in legislation. ${ }^{43}$ The Senate could not participate in the appointment of the first judges in 1993, because at the time it had still not been set up, so its powers were exercised by the lower house, the House of Representatives (Poslanecká sněmovna) instead.

An appointment procedure close to the American-Czech model was introduced in Slovenia, where it is the lower house of the parliament that votes on the candidates of the President. It is important to note that the Slovenian Parliament differs considerably from its Czech counterpart, as it is characterised by an asymmetric duality, which means that the two houses are not accorded equal powers. ${ }^{44}$ The judges of the Constitutional Court are appointed by the National Assembly (Državni bor), while the National Council (the Državni svet, composed of representatives of social, economic, professional and local interests) is not involved in the procedure at all. There is also a formal difference between the Czech and the Slovenian procedures: even if there is a parliamentary vote in both, the Czech solution appears as an appointment (confirmed by another body, the Senate), while the Slovenian one is an election (on proposal by a single person, the head of the state).

The exact opposite of the American-Czech solution can be found in the Slovak Republic, where the roles are inverted. There it is the unicameral parliament that can propose candidates and the head of state may confirm them. The parliament (Národná rada, which literally means National Council) shall propose double the number of candidates for judges that shall be appointed by the President of the Republic. ${ }^{45}$ The Constitutional Court Act determines which bodies can submit proposals for candidates: all members of the parliament, the government, the President of the Supreme Court, the Attorney General,

${ }^{41}$ See art. 54-66 of the Czech Constitution. Its text is available in English at http://www.psp.cz/ cgi-bin/eng/docs/ laws/1993/1.html (last access on 21 December 2012).

42 See art. 18 (2) of the Czech Constitution. On the other hand the lower house is elected under the principles of proportional representation.

43 The Senate has no say on the state budget and is much weaker in normal legislating activities (its veto can be overridden by a majority of all deputies). Its agreement is necessary only for constitutional amendments, some special laws and the ratification of international treaties. See KühnKysela: op. cit. 190-191.

${ }^{44}$ See art. 80-101 of the Slovenian Constitution, available in English at http://www.us-rs.si/en/ about-the-court/legal-basis/constitution/ (last access on 21 December 2012). See also Decision no. U-I-275/07 of 22 October 2008 of the Slovenian Constitutional Court.

45 See art. 134 (2) of the Slovak Constitution, available in English at http://www.concourt.sk/ en/A_ustava/ustava_a.pdf (last access on 21 December 2012). 
professional bodies of lawyers, academic institutions, and even the President of the Constitutional Court itself.46

Finally, also the first constitutional court of the world, conceived by Hans Kelsen, uses the collaborative model for the appointment of constitutional judges. In Austria, judges are appointed by the President, like in the Slovak Republic, but the power of proposing candidates is divided between the federal government and the two houses of the federal parliament. ${ }^{47}$ However, it cannot be seen as a reception or a variation of the American model, even if that precedes it in time. In the beginning, between 1920 and 1929, the Federal President and the Federal Government were not involved in the procedure, but appointments were equally divided between the two houses of the federal parliament. Moreover, the Austrian Constitutional Court has a quite unique composition. It has also six substitute members who participate in decision-making in case of impediment of an ordinary member. They are also appointed by the Federal President on the proposal of the above-mentioned three bodies, but the Bundesrat, the upper house of the federal parliament, can make a proposal only for one candidate, while the Nationalrat, the lower house, for two. The other half of the candidates (three) are proposed by the Federal Government also in this case. ${ }^{48}$ Another important rule is that the power of proposal of the Federal Government is restricted in comparison with that of the two houses of the federal parliament. The executive shall choose from among judges, administrative officials and law professors, while for the other candidates the general rule applies, i.e. they must have completed their studies in law and political science and have at least 10 years professional experience. ${ }^{49}$

Thus, in the collaborative model two branches of government cooperate in the appointment of judges, and these branches are typically the executive and the legislative ones. In none of the above mentioned systems is the judicial branch involved in the appointment procedure.

\section{The parliamentary model}

The parliamentary model is the simplest one from the procedural point of view: one body holds the power of appointment, and that is the parliament. In Europe Germany, Hungary and Poland belong to this category. There are, however, important differences between them. The German and the Hungarian solutions aim at obtaining a consensus on the candidates among the political parties, while the Polish system does not make any effort in this sense. Both the unicameral Hungarian and the bicameral German parliament elect constitutional judges by a two-thirds majority. In Germany half the judges are elected by

46 See art. 11 of the Slovak Constitutional Court Act, available in English at http://www. concourt.sk/en/ Act_38_1993/a_38_1993.pdf (last access on 21 December 2012).

47 The Austrian Court is composed by 14 members. Half of them, including the President and the Vice-President are appointed on proposal by the federal government, while the two houses of the federal parliament (the Nationalrat and the Bundesrat) can propose three candidates each. See art. 147 of the Austrian Constitution, available in English at http://www.vfgh.gv.at/cms/vfgh-site/english/ downloads/englishverfassung.pdf (last access on 21 December 2012).

48 It is provided for the same article in the Constitution that sets out the appointment procedure for the ordinary members (art. 147).

49 See art. 147 (2)-(3) of the Austrian Constitution. Rules of incompatibility are set out in the fourth paragraph. 
the Bundesrat (the upper house) and half by the Bundestag (the lower house).$^{50}$ In the latter the election is indirect, as the members or the Bundestag first elect a twelve-man electoral committee. ${ }^{51}$

In Hungary, the candidates are chosen by a parliamentary committee composed of representatives of the political parties represented in Parliament. This system has been upheld also by the new constitutional framework, ${ }^{52}$ but an important change was made in the procedure in June 2010 even before the adoption of the new Fundamental Law. Before this amendment the nominating committee was composed of one representative of each parliamentary group, irrespectively of its number of seats in parliament. Today the composition has to reflect the weight of the parties in the parliament. This is a novelty of crucial importance, as before the government did not necessarily dominate the nominating committee. It depended on the number of parties represented in the parliament. If there were more parties in the opposition then in the government, the opposition could play a decisive role in the nomination process. Today it cannot happen, as the government always gives the majority of the committee.

The Polish solution differs from the Hungarian and the German ones already in the nomination stage. Even if the Polish parliament is bicameral like the German, here only the lower house (the Sejm) is involved in the appointment procedure. Candidates can be proposed by at least 50 deputies or the Presidium of the Sejm, which is composed of 460 members. ${ }^{53}$ It means that the also opposition can propose its own candidates. However, they are very rarely elected to the Constitutional Tribunal, since the law requires only an absolute majority of the votes for the election of a constitutional judge. ${ }^{54}$ Between 1989 and 2002, only two of the 27 constitutional judges had been nominated by the opposition. ${ }^{55}$ It is obvious that this system exposes the appointment procedure to a bigger political influence. However, the law requires rather high qualifications from candidates, which exclude the appointment of politician without experience in law. ${ }^{56}$ In practice most of the Polish constitutional judges have been law professors. ${ }^{57}$ It may seem to be a paradox, but the absolute majority voting system was able to produce one of the most prestigious

50 See art. 94 of the German Basic Law, available in English at https://www.btg-bestellservice. de/pdf/80201000.pdf (last access on 21 December 2012).

${ }^{51}$ See art. 6 of the Federal Constitutional Court Act (BVerfGG) of 12 March 1951.

52 See art. 32/A (5) of the former Constitution. The new Fundamental Law does not contain any provision on the composition of the nominating committee, but it is now regulated by the new Constitutional Court Act (Act no. CLI of 2011, art. 7).

53 Art. 5(4), of the Constitutional Tribunal Act, available in English at http://www.trybunal.gov. pl/eng/Legal_Basis/ Act_Trib97.htm (last access on 21 December 2012).

54 The Constitution specifies that the judges are chosen by the Sejm individually, so a single vote for a group of candidates is not possible. Art. 194(1) of the Polish Constitution, available in English at http://www.sejm.gov.pl/ prawo/konst/angielski/kon1.htm (last access on 21 December 2012).

55 See Garlicki, L. L.: The Experience of the Polish Constitutional Court. In: Sadurski, W. (ed.): Constitutional Justice: East and West. The Hague-[etc.], 2002. 265-282, 268.

56 Art. 5 (3) of the Constitutional Tribunal Act provides that a judge of the Tribunal must possess the necessary qualifications to hold the office of a judge of the Supreme Court or the Supreme Administrative Court.

5724 out of 36 elected between 1985 and 2001. See Garlicki: op. cit. 269. 
constitutional courts of Central and Eastern Europe, notwithstanding the complete lack of counterweight to the power of the government to appoint constitutional judges. ${ }^{58}$

As regards the German appointment system, it is important to mention that even if it is a parliamentary model, as the all sixteen members are elected by the legislator, six of them (three in both panels) have to be judges of one of the federal supreme courts. ${ }^{59}$ So the German solution contains elements from the split model as well, even if the candidates are chosen by the parliament, not by the supreme courts. The reason may lie in the fact that the German system of administration of justice is rather fragmented, with five separate supreme courts at its top, so it would be more difficult to provide for an appointment by these courts. In Italy the five positions are divided between the three supreme courts, as explained above, while in Germany six positions should be divided between five supreme courts.

\section{A comparative analysis}

Having carefully examined the different appointment procedure models, it can be noted that even though it depends to a great extent on the political and constitutional framework of the country, we cannot find precise connections between a certain model and a certain form of government. It is not possible to state that semi-presidential systems prefer a type of appointment, while parliamentary systems prefer another type. Every country elaborated its rules on the basis of different considerations.

It is a fact that the appointment of constitutional judges is very much exposed to political games in the parliamentary model. There is a need for a compromise, and consequently for a political game, if the judges have to be elected by two-thirds majority. It is the case in Germany, but not in Poland where an absolute majority is sufficient. Both in Germany and in Hungary the application of the parliamentary model has resulted in the selection of the candidates being based on an accord among the leading political parties. In this model the political affiliation of the candidate plays a fundamental role in the appointment procedure. ${ }^{60}$ On the basis of the German and Hungarian experiences, in the two-thirds majority model it often happens that a compromise cannot be reached on one vacancy, and the political parties wait for at least a second vacancy to reach an accord by dividing the candidacies between each other. ${ }^{61}$ The danger of this practice is that if too many vacancies are left unoccupied, the court may become inoperative. Every constitutional court is subject to a quorum. For the German Federal Constitutional Court this quorum is six judges (out of eight) in each panel, ${ }^{62}$ while for the Hungarian Constitutional Court it was eight judges (out of eleven) before the constitutional reform, and is ten judges (out of

58 See also Kühn-Kysela: op. cit. 187.

59 Moreover, only those Supreme Court judges can become a candidate who held that position for at least three years. See art. 2(3) Federal Constitutional Court Act (BVerfGG) of 12 March 1951.

${ }^{60}$ According to Louis Favoreu several judges of the German Federal Constitutional Court have even a party card of CDU or of the SPD. See Favoreu, L.: Les Cours constitutionnelles. Paris, 1992. See also Luther, J.: La giustizia costituzionale nella Repubblica Federale di Germania. In: Luther, J.Romboli, R.-Tarchi, R. (eds): Esperienze di giustizia costituzionale. Tomo I. Torino, 2000. 159-198, $162-163$.

${ }^{61}$ It happened in Germany for example in 1984, when the parliamentary parties waited for four vacancies to open up in order to reach a compromise between the CDU and the SPD. At the same time they agreed even upon the person of the future President of the Court, to be elected in three years. See Favoreu: op. cit.

62 See art. 15 (2) BVerfGG. 
fifteen) today. ${ }^{63}$ However, in Germany it is possible to designate judges of the other panel as substitutes until the quorum has been reached, while in Hungary there is no such possibility for the plenary session, as there is no second chamber to draw from.

The split model is not free from political influence either. For the appointment of those judges who are chosen by the parliament the same logic applies as mentioned above. Moreover, the political influence is not necessarily limited to these appointments, as the Italian example shows. In Italy the appointments made by the three supreme courts (the Court of Cassation, the Council of the State and the Court of Auditors ${ }^{64}$ ) are the result of a compromise between the different judicial associations and reflect their political strength and division of power. ${ }^{65}$ Therefore it seems that even in the split model a deadlock can occur in the appointment procedure if the involved actors cannot reach an agreement. It happened in Italy right after the creation of the Corte costituzionale, when for eight years the court could not start operating because the Christian Democrats were unable to obtain the consent of the Socialists and the Communists until $1955 .{ }^{66}$ It happened also later on that a vacancy was filled after more than one year (the vacancies created by the retirement of Judge Caianiello from 1995 to 1997 and of Judges Guizzi and Mirabelli from 2000 to 2002). ${ }^{67}$

Finally, the collaborative model, which was chosen by the Czechs, the Slovaks and the Slovenians, needs the active cooperation between the head of the state and the parliament. An important element of the Czech model is the rule that provides for a deadline of sixty days for the consent of the Senate. In virtue of art. 6, par. 2, of the Czech Constitutional Court Act, if the Senate does not decide within sixty days, the President can appoint his candidate. ${ }^{68}$ Even this solution does not ensure, however, that the vacancy will be filled in, as the Senate may expressly refuse to give its consent. The deadline is for the decision, but this decision does not necessarily have to be positive. Actually it happened during the first term of President Vaclav Klaus (2003-2008) that the parliament rejected four out of his five candidates. In the summer of 2003 ten out of the fifteen judges retired at the same time from the court (all the members of the first Czech Constitutional Court had been appointed by President Vaclav Havel in 1993), and the Court remained without a sufficient number of

${ }^{63}$ See art. 30 (3) of the old Constitutional Court Act (Act no. XXXII of 1989) and art. 48 (4) of the new Constitutional Court Act (Act no. CLI of 2011).

${ }^{64}$ In Italian Corte di cassazione, Consiglio di Stato and Corte dei conti.

65 See Volcansek: op. cit. 377.

66 In this transitional period, between 1948 and 1956, ordinary judges exercised judicial review and did not apply laws that they considered unconstitutional, in virtue of Article VII of the Transitory and Final Provisions of the Constitution. See Cappelletti, M.: Judicial Review in the Contemporary World. Indianapolis, 1971. 49-50.

${ }^{67}$ See Pugiotto, A.: „Se non così, come? E se non ora, quando?” Sulla persistente mancata elezione parlamentare di un giudice costituzionale. In: Forum di Quaderni Costituzionali. 2008. Available at http://www.forumcostituzionale.it/site/ images/stories/pdf/documenti_forum/paper/0075 pugiotto.pdf (last access on 21 December 2012).

68 A considerable side-effect of the 60-days deadline is that it hampers any serious public discussion and creates an obstacle to the public openness of the process. See Kühn-Kysela: op. cit. 205-206. 
judges for more than a year. ${ }^{69}$ The deadlock was broken by the 2004 parliamentary elections in which Klaus' party won almost half of the seats in the Senate.

From the comparison of the different models and of their practical application it emerges clearly that each of them struggles with the problem of filling vacancies without delay. The issue therefore merits further examination.

\section{Is it possible to avoid standstills in the appointment procedure?}

One of the most difficult problems in any of the above-mentioned models is how to fill vacancies in good time. As already explained above, every constitutional court is subject to a quorum, so the eventual incapacity of the court to make decisions is not unrealistic at all. It happened in the Czech Republic, but there was this danger also in Hungary, where the Constitutional Court worked with eight judges for more than six months in $2005,{ }^{70}$ and again in 2010 when it took one and a half year to appoint two new judges. ${ }^{71}$

Therefore, on the basis of these experiences, the legislator has to pay attention to the problem of possible standstills when regulating the appointment procedure, independently from the model chosen. It is difficult to imagine an effective sanction that could constrain the parliament or the other bodies to appoint a new judge, and there is no such sanction in the European panorama. The only legislative solution found for this problem so far has been the institution of the so-called prorogatio which means that the retiring judge remains in office until the appointment of his successor. This solution was introduced in Slovenia and in Latvia, and it follows the logic of the "lesser evil". If on one side the term of office of the retiring judge is extended without a democratic legitimation, on the other side it is a secure way of avoiding vacancies and preventing the Court from becoming inoperative. If the legislator decides to adopt this solution, it is necessary necessary to introduce the respective rule in the constitution. A comparative analysis shows that regulation on the legislative level may not be adequate, as it may raise concerns about its conformity with the constitution if it provides for the length of the term of office. This question emerged in Bulgaria, where the Constitutional Court with its decision delivered on 7 March 2006 annulled a provision of the Constitutional Court Act providing for the extension of the term of office of the retiring judge until the appointment of his successor. It is worth mentioning that the constitutional review in that case was initiated by the Public Prosecutor and concerned also the extension of the term of office of other public offices (such as the mayor, the presidents of the two supreme courts and the public prosecutor himself). According to the Bulgarian Court this extension violated the constitutional norm that provided for a 9-year term of office for constitutional judges.

69 At the climax of the conflict between the Senate and the President, one senator proposed the President's impeachment. No one else wanted to support his proposal, but the Senate continued to reject most of the President's candidates. By the end of 2005, the Senate rejected seven nominations out of a total eighteen. See more in detail ibid. 198-199.

${ }^{70}$ The term of Judge (and President of the Court) János Németh expired in August 2003, of Judge Ottó Czúcz in May 2004 and of Judge János Strausz in December 2004. Until September 2005 the parliament was not able to appoint a new judge, so the vacancy of Judge Németh remained unfilled for two and a half years.

71 In the person of István Stumpf and Mihály Bihari. 
A violation of the constitution could not be issued on the same basis in Latvia where the Constitution is silent on the term of office of the constitutional judges. Therefore a challenge of the prorogatio before the Latvian Constitutional Court would not bring to the same result, or at least an annulment could not be done on the same constitutional basis. However, a violation of the rule of law and legal certainty can still be taken into consideration. A challenge is completely excluded in Slovenia where it is the constitution itself that regulates the prorogatio.

\section{Publicity of the appointment procedure}

Zdenek Kühn and Jan Kysela, two Czech legal scholars published an essay in 2006 on the appointment of constitutional judges in the formerly socialist countries, in which they make a comparison between the different models, using the Czech experience as case study. ${ }^{72}$ Their conclusion emphasises the importance of the appointment procedure's publicity. On the other hand, another recent article written by a former Minister of Justice of Germany, Brigitte Zypries, argues to the contrary. According to her, publicity is not a good idea at all. ${ }^{73}$ Both opinions are worth being examined.

As a matter of fact, appointment procedures in Europe today are far from being transparent, unlike in the United States. As already mentioned, the U.S. Supreme Court is often used as a point of reference in comparative studies both in legal and in political science. ${ }^{74}$ The American Justices, notwithstanding the clearly politicised appointment procedure, are considered the living symbols of judicial independence. According to Kühn and Kysela one of the most important elements of the U.S. appointment procedure is its high publicity. The "advice and consent" requirement contained in Article III of the federal Constitution resulted in a practice in which the Judiciary Committee of the Senate, created for the purpose of nominating judges, hears all the candidates before making its decision. These hearings receive high media attention and are usually broadcasted by the national television.

Parliamentary committees are involved in the appointment procedure even in the European parliamentary and collaborative models and, to a more limited extent, in the split model, but the hearings of the candidates are held behind closed doors, so the public is not able to follow them. Kühn and Kysela observe that: "The core of the nomination process lied neither in (...) committees' hearings nor in the final public plenary majority vote, but is moved elsewhere. The 'European' tendency not to discuss controversial issues publicly is apparent in the Czech practice, which shifts most contested issues from public hearings to closed and secret hearings in political caucuses regarding the candidates."75

It is a fact that in Europe, both in the East and in the West, the appointment of constitutional judges is not a major media event. We can find brief news about it in the newspapers and some critical comment in more specialised reviews, but they do not analyse in detail the negotiations taking place between the political parties and do not report about the committee hearings. While in the United States the appointment procedure wins the

72 See Kühn-Kysela: op. cit.

73 See Zypries, B.: The Basic Law at 60 - Politics and the Constitutional Court. German Law Journal, 11 (2011) 1, 87-98, 97.

${ }^{74}$ See supra at I.2.

75 See Kühn-Kysela: op. cit. 201. 
headlines, in the European media these news take the form of a short communication or in any case the relevant article may be found among the news of secondary importance.

This difference is due to the different role judges have in continental Europe. In the common law systems a judgment is a personal decision that expresses the opinion of the judge and is linked to his person. This approach opens the door to dissenting opinions. If a judgment expresses the opinion of the judge (and, indeed, they are called also "opinion" which is often used as a synonym of "judgment"), it is self-evident that in a panel of judges disagreements can occur. In the common law mentality it is not perceived as a problem. Judicial panels make majority decisions and also the opinion(s) of the minority is published. ${ }^{76}$ The continental European legal tradition conceives judicial decisions in a completely different way. It does not recognise their personal nature, therefore eventual disagreements between the judges are hidden. It is not true, however, for constitutional courts, most of which allow the publication of dissent. It is not for this paper to study in depth the practice of dissenting opinions, but it worths observing that there is an apparent contradiction in the European practice as regards constitutional courts. Constitutional judges in almost all European countries can publish dissenting opinions, ${ }^{77}$ so it is possible to follow the development of their legal philosophy and to check eventual changes or inconsistencies in it, but their appointment does not attract the attention of the public. As Kühn and Kysela observe, in Europe people still believe that the court decides, not its individual judges. ${ }^{78}$ Moreover, hearings before the nominating committee are held behind closed doors and the public voting in the parliament is a pure formality. The conclusion of the Czech scholars on East-Central Europe is particularly eye-opening: "The absence of a strong civil society in the post-communist region effectively means that political deadlock is not perturbed by other channels, for instance by citizens' pressure on relevant institutional actors, which would push them to reach compromise."79 Thus, shortcomings can be found not only in the institutional structure and the appointment procedure, but also in the political culture. It is not a coincidence that the problem of standstill in appointment procedures emerged more often in the formerly socialist countries. With the strengthening of civil society also the publicity of appointments has been increasing.

On the other hand, if we look at Western European countries with a strong civil society, like Germany, different arguments have been advanced. A recent legislative proposal from the Alliance 90/The Greens called for greater transparency in judicial appointments by subjecting candidates to a public hearing. Zypries argues that it would be dangerous, as public hearings might be used to attempt to discredit people with allegedly unsuitable values. She also points out however that it can happen even if there is no public hearing, as was the case for the last Vice President of the Court. ${ }^{80}$ Of course, public hearings increase this danger. Examples can be brought from the American practice (see the controversy surrounding the confirmation hearings of Justice Clarence Thomas in 1991). But is it a sufficient reason for hiding the procedure from the public, or is it

${ }^{76}$ For a more detailed account of the comparative history of dissenting opinions see Kelemen, K.: The Road from Common Law to East-Central Europe: The Case of the Dissenting Opinion. In: Cserne, P.-Könczöl. M. (eds): Legal and Political Theory in the Post-National Age. Frankfurt-[etc.], 2011. 118-134.

77 The exceptions are Austria, Belgium, France, Italy and Luxembourg.

78 See Kühn-Kysela: op. cit. 205.

79 See ibid. 208.

80 See Zypries: op. cit. 97. 
counterbalanced by the benefits that it brings? It exposes the candidates to the danger of becoming the object of a political campaign, but it also exposes them to the scrutiny of the public and of civil society.

\section{Proposal: a new appointment model for the Hungarian Constitutional Court}

On the basis of the problems emerged in practice, it seems clear that the Hungarian model of appointment has not been able to achieve the objective that judges should be appointed on the basis of a political compromise. ${ }^{81}$ In practice this compromise has never been reached with respect to the single candidates but vacancies have been divided between the leading political parties. The constitutional amendment adopted in 2010 made the situation even worse. The same solution was upheld by the new Fundamental Law which entered into force on 1 January 2012. Considering the current composition of the Hungarian parliament and the two-thirds majority held by the government coalition, today the opposition can be completely excluded from the selection of candidates.

My proposal is to introduce the split model for the appointment of the judges of the Hungarian Constitutional Court. Among the existing three models of appointment this is the one that ensures better that the composition of the Court expresses a balance between the branches of government. Even if the form of government of Hungary is not semipresidential but parliamentary, on the basis of foreign experiences the head of state (the President of the Republic) may play an important role in the selection of constitutional judges (see the Italian, Austrian, Czech and Slovak examples). In virtue of art. 9, par. 1, of the new Fundamental Law it is the duty of the President of the Republic to safeguard the democratic operation of state organisation. The independence of the Constitutional Court is without doubt an important element of democratic operation. So it would be in conformity with the constitutional role of the head of the state to confer on him this competence. However, unlike in the collaborative model, in the split model only one-third of the constitutional judges would be appointed by him.

The Hungarian Constitutional Court has worked with 15 judges since September 2011. It is therefore easy to divide the appointment between three different bodies: all three could appoint five judges. One-third of the judges would be appointed by the President of the Republic, one-third by the parliament and one-third by the ordinary judiciary. The old procedure (the one in force before the 2010 constitutional amendment) could be applied to the parliamentary appointments, so a parliamentary committee composed of one representative of each parliamentary group would choose the candidates, and the parliament would elect them by a two-thirds majority. As to the appointments by the judiciary, there are more possible solutions. András Jakab, a Hungarian legal scholar, in his private constitutional draft proposed to give this power to the President of the Curia (the Hungarian Supreme Court) on proposal by the majority of the Presidents of the Courts of Appeal. ${ }^{82}$

${ }^{81}$ See also the letter of László Sólyom, then President of the Republic, with which he sent back to the parliament the constitutional amendment changing the composition of the nominating committee, available (in Hungarian) at http://www.solyomlaszlo.hu/admin/data/file/6939_20100621_ visszakuldo_level_alkotmanybirok_cimerrel.pdf (last access on 21 December 2012).

${ }^{82}$ See p. 46 of the private draft of András Jakab, available (in Hungarian) on the website of the Pázmány Péter University: http://www.jak.ppke.hu/tanszek/alkotm/letolt/alkt.pdf (last access on 14 September 2012). 
Another alternative is to confer this power on the plenary session of the Curia which would decide by majority. ${ }^{83} \mathrm{~A}$ third alternative is offered by the Spanish solution: it is the judicial self-governing body, the General Council of the Judiciary that appoints one-third of the constitutional judges by a three-fifth majority. ${ }^{84}$ In Hungary there is only one supreme court, unlike in other European countries where there are also special (administrative, financial, etc.) supreme courts, so the adoption of the second solution would be possible, and the appointments would not have to be divided between a number of supreme courts, like in Italy. If the decision is taken by all judges of the Curia, it would avoid the potential risks of conferring this power on one single person, the President of the Curia (even if on proposal by the Presidents of the Courts of Appeal, as suggested by Jakab). However, the third (Spanish) solution is also viable. In this case, one-third of the constitutional judges should be appointed by the National Judicial Council (Országos Bírói Tanács), and not by the President of the National Judicial Office (Országos Bírósági Hivatal), as it is the former that is an independent self-governing body of the judiciary, while the latter is elected by the parliament. $^{85}$

Concluding, my proposal is to introduce the split model in which five constitutional judges would be appointed by the President of the Republic, five would be elected by the Parliament (by a two-thirds majority and on proposal of the nominating committee composed of an equal number of representatives from each parliamentary party), and five would be appointed by the plenary session of the Curia. However, the constitutional and legislative provisions offer only a framework for the appointment procedure. Its practical application depends to a large extent on the political culture of country, as shown by the foreign and domestic experiences.

${ }^{83}$ A similar solution is adopted in Italy, where the appointment is made by a panel composed of all members of the Supreme Court, including the prosecutors. See art. 2 of Act no. 87 of 11 March 1953, available (in Italian) at http://www.giurcost.org/fonti/187-53.htm (last access on 21 December 2012).

${ }^{84}$ See art. 16 (1) of the Organic Law 2/1979 of 3 October 1979 on the Constitutional Court, and art. 107 (2) of the Organic Law 6/1985 of 1 July 1985 on the Judicial Power.

85 See art. 66 and 88 of Act no. CLXI of 2011 on the organisation and administration of courts. 